\section{Root-medium Nutrient Levels and Irrigation Requirements of Poinsettias Grown in Five Root Media}

\author{
William R. Argo ${ }^{1}$ and John A. Biernbaum ${ }^{2}$ \\ Department of Horticulture, Michigan State University, East Lansing, \\ MI 48824-1325
}

\section{Additional index words. Euphorbia pulcherrima, evaporation, irrigation, soluble salts}

\begin{abstract}
V-14 Glory' poinsettias (Euphorbia pulcherrima Willd. ex Klotzsch) were grown in five root media using top watering with $20 \%$ leaching for 112 days. Root media with a high water-holding capacity required fewer irrigations and fertilizer applications than those with a lower water-holding capacity. However, similar amounts of water were applied and leached with both types of root media over the entire experiment. The reduction in the number of fertilizations was compensated for by an increase in the amount (volume) of fertilizer applied at any one irrigation. The greatest differences in root-media nutrient concentrations were found between the top $2.5 \mathrm{~cm}$ (top layer) and the remaining root medium within the same pot (root zone). After 58 days, when fertilization with watersoluble fertilizer $\left(28.6 \mathrm{~N}-0 \mathrm{P}-8.5 \mathrm{~K} \mathrm{~mol} \cdot \mathrm{m}^{-3}\right)$ was stopped, nutrient concentrations in the top layer were 3 to 6 times greater than those in the root zone for all five root media tested. For the final 42 days of the experiment after fertilization was stopped, nutrient concentrations in the root zone remained at acceptable levels in all root media. The nutrients contained in the top layer may have provided a source of nutrients for the root zone once fertilization was stopped.
\end{abstract}

The efficient application of water and water-soluble fertilizer is important for the greenhouse industry to prevent water and fertilizer runoff into the environment (Biernbaum, 1992). A proposed method of reducing water and fertilizer runoff from greenhouses is the selection of root media with increased waterholding capacity (Biernbaum et al., 1989). The addition of components, such as rockwool, increases the water-holding capacity of a root medium (Fonteno and Nelson, 1990). Root media with a high water-holding capacity may allow a longer period between each irrigation, thus allowing fewer irrigations, which may reduce the amount of water and fertilizer runoff from greenhouse crops.

Root-medium nutrient buffering capacity may also reduce runoff. An adequate cation exchange capacity (CEC) is desired in a root medium to retain cations against the force of leaching and buffer the root medium from sudden changes in nutrient concentration (Bunt, 1988; Nelson, 1991), and it may also affect the pH management (Biernbaum, 1992). The CEC of peat is due to the presence of organic acids that are formed from the degradation of lignins in the plant cell wall (Puustjarvi and Robertson,

Received for publication 12 Sept. 1994. Accepted for publication 10 Jan. 1995. We acknowledge the support of the Michigan Agricultural Experiment Station (MAES) and the American Floral Endowment. The use of trade names in this publication does not imply endorsement by the MAES of the products named, nor criticism of similar ones not mentioned. The cost of publishing this paper was defrayed in part by the payment of page charges. Under postal regulations, this paper therefore must be hereby marked advertisement solely to indicate this fact. ${ }^{1}$ Graduate Research Assistant.

${ }^{2}$ Associate Professor.
1975). The more degraded the peat, the greater the amount of organic acids and the higher the CEC. Thus, CEC can be intuitively estimated from the degradation state of the peat.

Other components added to root media, such as perlite, polystyrene, and rockwool, have little or no CEC and are included in peatbased root media primarily to increase aeration or water-holding capacity (Nelson, 1991). Bark and vermiculite add aeration and nutrient retention to a root medium. Vermiculite is not typically added to root media in the same high percentage as peat, but bark is often used as a replacement for peat. Since individual components, other than peat, tend to be similar in most root media, the main difference in the buffering capacity of peat-based root media may be due to the peat itself.

Many experiments have been conducted to determine plant responses to root media that differ in physical and chemical properties. Often, the root media are watered and fertilized identically (Bilderback et al., 1982; Brown and Emino, 1981; Fonteno etal., 1981; Fonteno and Nelson, 1990). Root-medium nutrient concentrations are a function of fertilizer concentration applied and the leaching fraction (volume leached/volume applied) ( $\mathrm{Ku}$ and Hershey, 1991; Yelanich and Biernbaum, 1993). To compare nutrient concentrations in root media with differing water-holding capacities, the leaching fraction for each root medium should be the same. The total waterholding capacity and the amount of available water must be determined for each root medium individually, and irrigations must be scheduled accordingly (Argo and Biernbaum, 1994).

The objectives of this experiment were to monitor water use and leaching; track changes in electrical conductivity (EC), $\mathrm{pH}$, and nutrient concentrations in root media of various peat types and components that varied in water-holding capacity and expected nutrientbuffering capacity; and identify root medium characteristics that influence fertilization practices and soil test interpretations that require further study.

\section{Materials and Methods}

The design was a randomized complete block with five root media, eight sampling dates, and three replications per medium at each sampling date for a total of 120 plants. Data were tested using the analysis of variance procedures of SAS (SAS Institute, 1982). Statistics for the graphical data are presented as a single error bar and were calculated using a pooled standard error.

The root media used in this experiment were 1) Al-par Planting Mix (APM), composed of field-harvested muck soil, Canadian sphagnum peat, polystyrene, and limestone with a preplant nutrient charge (Al-par Peat Co., Ovid, Mich.); 2) Metro Mix 510 (MM 510), composed of Canadian sphagnum peat, vermiculite, composted pine bark, bark ash, and sand with limestone and a preplant nutrient charge (Grace Sierra, Allentown, Pa.); 3) Suremix Rockwool Mix (SRM), composed of Canadian sphagnum peat, medium grind rockwool (Partek North American, Brunswick, Ohio), and \#2 vermiculite (Terra-lite, Grace Sierra) with limestone and a preplant nutrient charge (Michigan Growers Products, Galesburg, Mich.); 4) peat A/vermiculite (PAV), composed of a Canadian sphagnum peat and \#2 vermiculite with limestone and a preplant nutrient charge; and 5) peat B/vermiculite (PBV), composed of a Michigan sphagnum peat and \#2 vermiculite with limestone and a preplant nutrient charge.

The types of peat used in media 2,3 , and 4 were long-fibered sphagnum peats with little dust (Von Post scale 1-2) (Puustjarvi and Robertson, 1975). The peat used in medium 5 was a short-fibered, more degraded sphagnum peat with a large amount of dust (Von Post scale 2-3). Medium 1 contained a long-fibered sphagnum peat with little dust and a highly degraded reed sedge peat muck that, when dry, was primarily dust (Von Post scale $>5$ ).

The experiment was conducted at Michigan State Univ., East Lansing, in a well-ventilated glass greenhouse with constant air circulation and cement floors. Rooted 'Gutbier V14 Glory' poinsettia cuttings were planted on 31 Aug. 1989 into 12-cm-tall $\times 15$-cm-wide (volume $=1.5$ liter) plastic pots containing one of the five root media. A total of 24 plants was randomly assigned to each root-medium treatment.

The water used in this experiment had a $\mathrm{pH}$ of 7.7; an EC of $0.6 \mathrm{dS} \cdot \mathrm{m}^{-1}$; an alkalinity to $\mathrm{pH}$ 4 of $310 \mathrm{mg} \mathrm{CaCO} /$ liter; and $2.0 \mathrm{Ca}^{2+}, 1.6$ $\mathrm{Mg}^{2+}$, and $1.0 \mathrm{Na}^{+}$(in mol.m ${ }^{-3}$ ). Between 12 Sept. and 29 Oct., fertilizer solution made from $\mathrm{KNO}_{3}$ and $\mathrm{Ca}\left(\mathrm{NO}_{3}\right)_{2}$ with a concentration of $28.6 \mathrm{~N}-0 \mathrm{P}-8.5 \mathrm{~K} \mathrm{~mol} \cdot \mathrm{m}^{-3}$ and an EC of 
$3.3 \mathrm{dS} \cdot \mathrm{m}^{-1}$ was applied at every irrigation. After 30 Oct., tap water was applied with every irrigation. The volume of water applied to each pot was multiplied by the fertilizer concentration to determine the grams of $\mathrm{N}$ fertilizer applied.

From planting until 11 Sept., plants were irrigated so that the root medium remained moist without saturation or leaching. On 11 Sept., all the plants were watered thoroughly with fertilizer solution and weighed. The watered weight was used as an estimation of the maximum amount of water that would be held in each root medium after an irrigation. Several additional plants grown in each root medium were allowed to dry to visible wilt, and the pots were reweighed. The weight at which the plants wilted was used as an estimation of the point at which the water held in the root media was no longer available to the plant. The difference between the watered weight and wilt weight was used as an estimation of the total amount of available water held in the root media after an irrigation.

After 11 Sept., each root-medium treatment was irrigated independently. Six plants from each root medium were weighed daily. Plants in each root-medium treatment were watered when the average weight of the six sample plants reached a target weight based on a loss of $75 \%$ to $85 \%$ of the available water. Sufficient water was applied for $20 \%$ leaching. The six sample plants were weighed before and after each irrigation to determine the amount of irrigation water absorbed by the root medium. The water leached from the pot was collected and measured to determine the average leaching fraction at each irrigation. The EC of the leachate was measured at every other irrigation to estimate nutrient concentration.

Root-medium samples were collected for 98 days from three pots per medium treatment every 14 days following planting. The top 2.5 $\mathrm{cm}$ was removed and discarded for the first five sampling dates and was removed and sampled separately for the final three sampling dates. Nutrients in the root media were sampled using the saturated media extraction (SME) technique (Warncke, 1986), using reverse osmosis purified water as the extractant. Root-medium $\mathrm{pH}$ was measured in the saturated media before extraction. Root-medium EC was determined from the extracted solution using a YSI model 32 conductance meter (Yellow Springs Instrument Co., Yellow Springs, Ohio) at a standard 25C.

\section{Results and Discussion}

The initial $\mathrm{pH}$ for the five root media averaged 5.7 and ranged from 6.3 with the MM 510 and the SRM to 4.6 with the PBV (Fig. 1). PAV and PBV had received a similar amount of limestone before planting, but at planting, there was a two-unit difference in the $\mathrm{pH}$. However, by 42 days, there was no difference in $\mathrm{pH}$ among the five root media. Root-medium $\mathrm{pH}$ generally increased after 56 days when fertilizer solution was no longer applied. MM 510 exhibited the greatest increase, rising from $\mathrm{pH} 5.7$ to 8.1 over the last 42 days of the experiment. Only with the PBV did the medium $\mathrm{pH}$ remain at acceptable levels (Warnke and Krauskopf, 1983) once fertilizer solution was no longer applied. APM, containing the highly degraded reed sedge peat, had a $\mathrm{pH}$ buffering capacity similar to that of media containing the long-fibered, less-degraded sphagnum peat (MM 510, PAV, SRM).

There was a relationship between decreasing root-zone $\mathrm{EC}$ and increasing root-zone $\mathrm{pH}$ once fertilization ceased. For example, the EC of MM 510 decreased from 5.1 to $1.7 \mathrm{dS} \cdot \mathrm{m}^{-1}$, and the $\mathrm{pH}$ increased from 5.6 to 8.0 over the last 42 days of the experiment. In contrast, the EC of the PBV decreased from 3.0 to 2.6 $\mathrm{dS} \cdot \mathrm{m}^{-1}$, and the $\mathrm{pH}$ increased slightly from 5.9 to 6.0 over the same period.

A 20\% leaching fraction was not sufficient to maintain nutrient concentrations in the root zone within the optimal soil test concentrations while fertilizer was being applied in all root media tested (Fig. 1). Either a reduction in the concentration of the applied fertilizer solution or an increase in the leaching fraction would be necessary to maintain root-zone nutrients within the recommended soil test concentrations (Warncke and Krauskopf, 1983), as recommended by $\mathrm{Ku}$ and Hershey (1991) and Yelanich and Biernbaum (1993).

The greatest differences in nutrient concentrations did not occur between the root media, but instead were found within the pot itself. The top $2.5 \mathrm{~cm}$ of medium (top layer) in the pot contained soluble salt concentrations several times higher than those measured in the remaining portion (root zone) (Fig. 2). When the top layer of the media was tested 14 days after fertilization stopped, the EC was 2 to 3 times higher than that of either the root

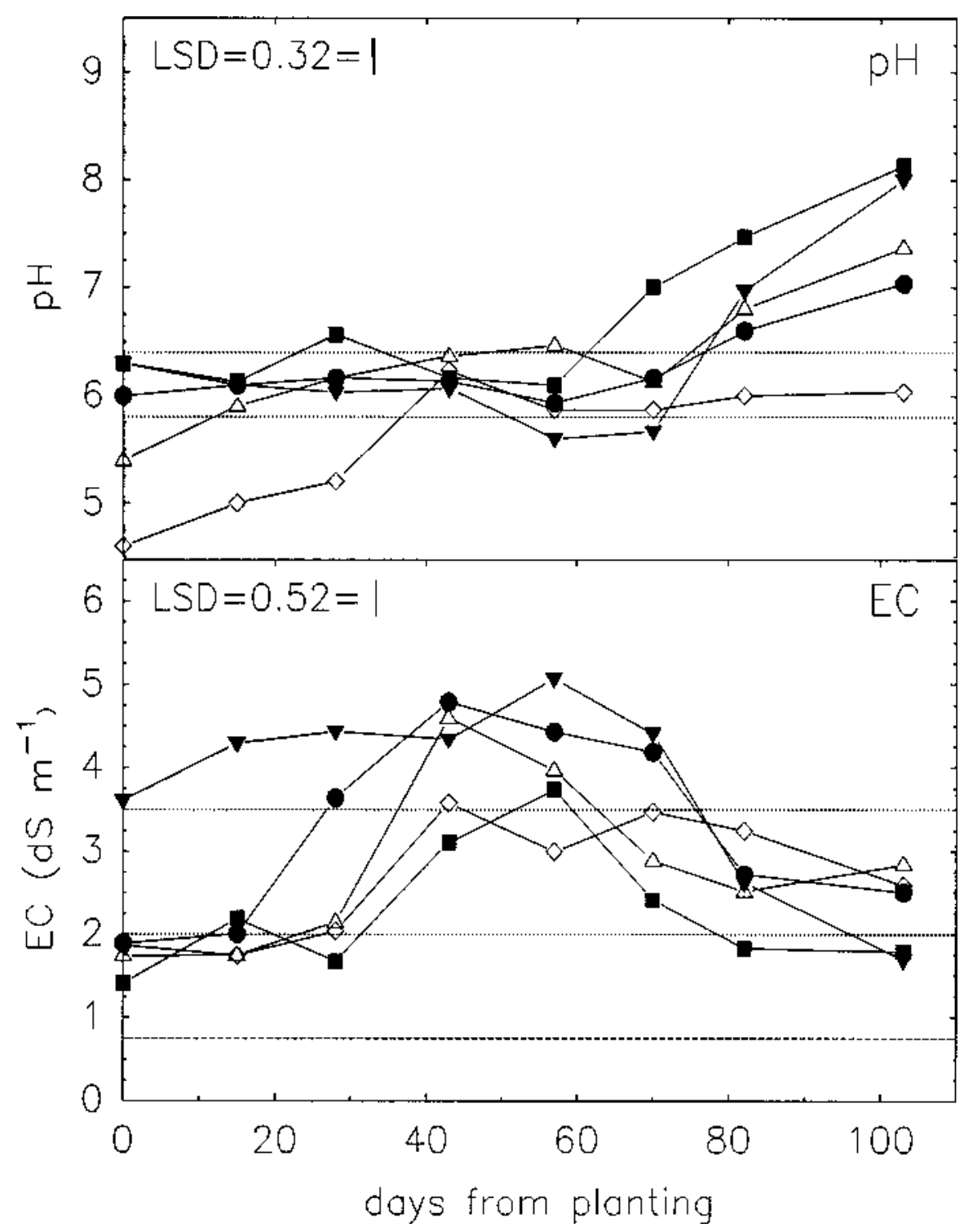

Fig. 1. Root medium $\mathrm{pH}$ and electrical conductivity (EC) levels for top-watered poinsettias grown in five root media with $20 \%$ leaching. Samples were taken at 14-day intervals after planting. APM $(\bullet)=$ Alpar Planting Mix, MM $510(\boldsymbol{\nabla})=$ Metro Mix 510, SRM $(\mathbf{\square})=$ Suremix Rockwool Mix, PAV $(\Delta)=$ peat $\mathrm{A} /$ vermiculite, $\mathrm{PBV}(\diamond)=$ peat $\mathrm{B} /$ vermiculite. Dotted lines indicate the recommended optimal range(s) and lower dashed lines the recommended acceptable range(s) for the standard medium extract (Warncke and Krauskopf, 1983). Mean separation using pooled standard error of the data presented by least significant difference, $P \leq 0.05$. 


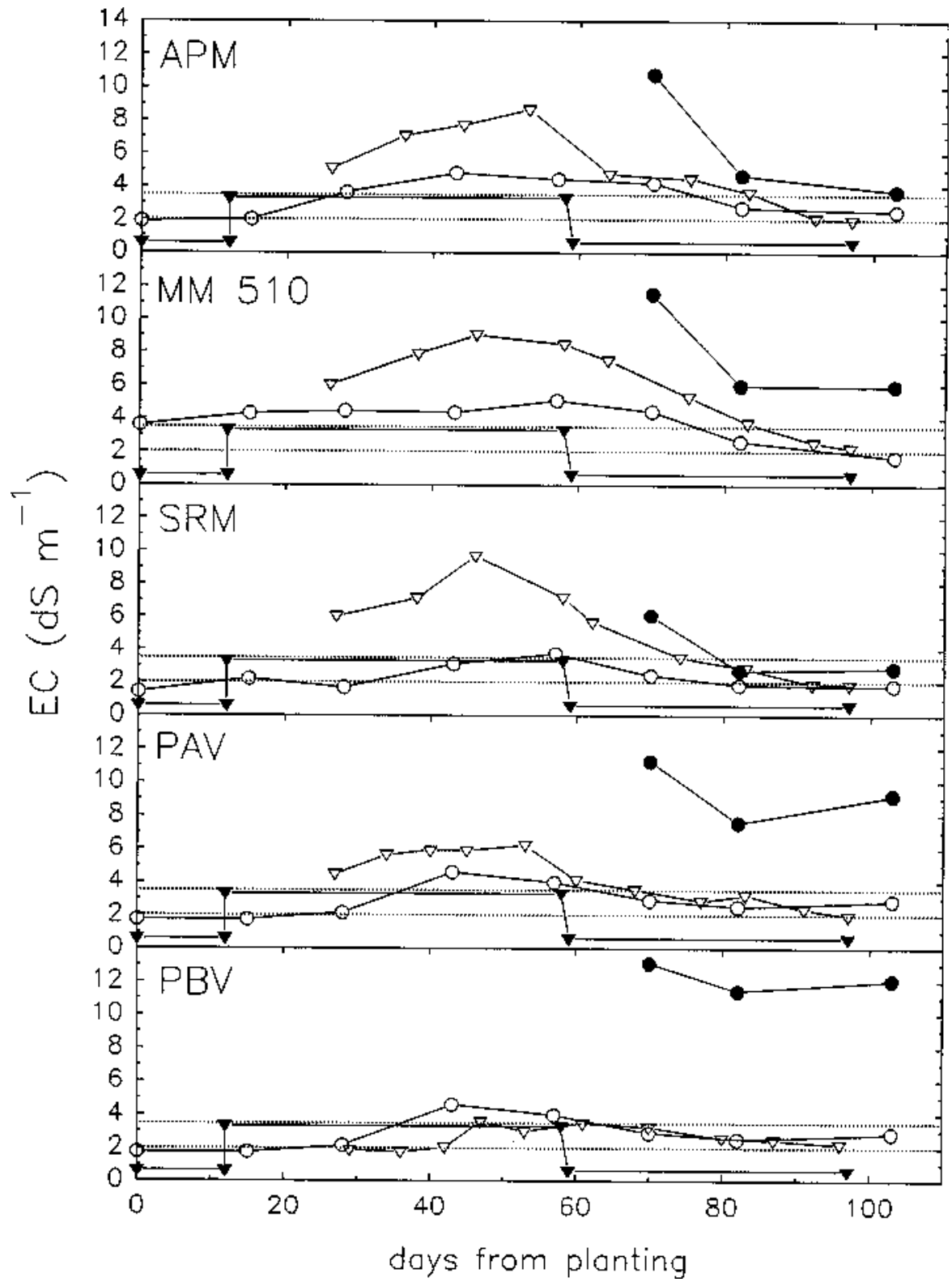

Fig. 2. Electrical conductivity (EC) levels measured in the root zone $(\bigcirc)$, top layer $(\bullet)$, leachate $(\nabla)$, and applied fertilizer solution or water $(\boldsymbol{\nabla})$ in five root media. Dotted lines indicate recommended optimal EC ranges for the standard medium extract (Warncke and Krauskopf, 1983). Mean separation using pooled standard error of the data presented by least significant difference $(5 \%)$ is $0.47 \mathrm{dS} \cdot \mathrm{m}^{-1}$.

zone or the leachate. In all root media but SRM, the top-layer EC remained higher than that of either the leachate or root zone for the remaining 28 days of the experiment. In general, the $\mathrm{EC}$ of the top layer was closer to the root-zone EC in root media that received greater amounts of water at any one irrigation (MM 510). In comparison, $\mathrm{PBV}$ received the least amount of water at an irrigation, and the EC of the top layer remained constant over the final weeks of the experiment. In the SRM, which received the most water at a single irrigation, the EC of the top layer and the root zone were similar for the final 42 days of the experiment.

Root-zone EC (Fig. 2) and macronutrient concentrations (data not shown) remained at or near levels normally considered optimal for an SME soil test after 42 days of irrigations with only tap water. Perhaps the high concen- tration of fertilizer salts in the top layer acted as a nutrient reservoir for the plant after fertilization stopped. The $20 \%$ leaching fraction was not sufficient to remove the high concentration of fertilizer salts in the top layer of the root media at any one irrigation. Instead, nutrients were washed down from the top layer gradually, thus buffering the root zone from a rapid decrease in nutrient concentrations.

One hypothesis for the difference in toplayer nutrient concentrations between media is related to differences in CEC due to the degradation of the peat (Puustjarvi and Robertson, 1975) or the presence of an inert component, such as rockwool, compared to vermiculite. Perhaps the top layer of the PBV was able to absorb and retain a greater percentage of the applied nutrients then the SRM. A second hypothesis is that there were differ- ences in capillary water movement to the top layer with the various media. Fonteno and Nelson (1990) reported that for media containing rockwool, the percentage of water held in the top of the pot was less, and the percentage of water held in the bottom of the pot was greater than that measured in non-rockwoolcontaining media. Thus, the lower top-layer EC in the SRM may have been related to less water and less of the nutrients moving to the root medium surface compared to the PBV. A third hypothesis is based on differences in the rewetting characteristics of the media. Argo and Biernbaum (1993) found that moredegraded peats were less efficient at absorbing applied irrigation water than less-degraded peats after several months of production. The lower top-layer EC in the SRM may be a result of more efficient leaching compared to the $\mathrm{PBV}$. Additional research is needed, since all three hypotheses adequately explain differences in top-layer nutrient concentrations.

While the plants were being fertilized, leachate $\mathrm{EC}$ was higher than root-zone $\mathrm{EC}$ in four of the root media (Fig. 2). In general, the difference between leachate EC and root-zone $\mathrm{EC}$ was greater in root media with longer intervals between irrigations (APM, MM 510, and SRM). In the PBV, leachate EC was lower than root-zone EC over the same period. Once fertilization stopped, leachate EC and rootzone EC were similar in three of the root media. The leachate EC of the SRM and the MM 510 remained higher than the root-zone EC until the end of the experiment.

The total number of irrigations applied to the various root media ranged from 15 to 21 between 26 Sept. and 6 Dec. (Table 1). The SRM medium held the most water after a "normal" irrigation (0.59 liters), was watered the fewest number of times (15), and received the most water per plant. The PAV root medium leached the most water. Actual calculated leaching fractions ranged from $18 \%$ for the SRM and MM 510 to $22 \%$ for the PAV.

The number of fertilizer applications ranged from nine in the SRM and MM 510 to 15 in the PAV (Table 1). The greatest difference in the amount of applied $\mathrm{N}$ fertilizer was between the PAV and the MM 510. Plants grown in PAV received $0.4 \mathrm{~g} \mathrm{~N}$, or 1.0 liter more of the 28.6 $\mathrm{mol} \mathrm{N} / \mathrm{m}^{3}$ solutions, than plants grown in the MM 510.

Plants grown in the SRM were taller, heavier (fresh and dry weight), and had larger bracts than plants grown in the other root media (Table 2). The reason for differences in plant growth among the five root media is unclear. There was not an obvious relationship between the volume of water applied, final media, or tissue nutrient concentrations (data not shown) with plant size or leaf area. The difference in growth may be related to the amount of available water contained in the root medium after an irrigation (Fonteno et al., 1981).

One of the major concerns about root media that hold large amounts of water is that if fertilizer is not applied frequently, nutrients will become limiting. However, the amount of fertilizer applied is a function of the number of applications and the amount of solution that 
Soil Management, Fertilization, \& Irrigation

Table 1. Water and fertilizer application for poinsettia grown in five root media from 26 Sept. until 6 Dec. 1989. All values are on a per-pot basis.

\begin{tabular}{|c|c|c|c|c|c|c|c|}
\hline Root media $^{2}$ & $\begin{array}{c}\text { No. } \\
\text { irrigations }\end{array}$ & $\begin{array}{l}\text { Water applied/ } \\
\text { irrigation } \\
\text { (liters) }\end{array}$ & $\begin{array}{l}\text { Water absorbed/ } \\
\text { irrigation } \\
\text { (liters) }\end{array}$ & $\begin{array}{l}\text { Total water } \\
\text { absorbed } \\
\text { (liters) }\end{array}$ & $\begin{array}{c}\text { Total water } \\
\text { leached } \\
\text { (liters) }\end{array}$ & $\begin{array}{c}\text { No. } \\
\text { fertilizations }\end{array}$ & $\begin{array}{l}\text { Applied N } \\
\text { fertilizer } \\
(\mathrm{g})\end{array}$ \\
\hline$\overline{\mathrm{APM}}$ & 16 & 0.56 & $0.43 \mathrm{c}^{\mathrm{x}}$ & $6.9 \mathrm{c}$ & $1.9 \mathrm{ab}$ & 11 & 2.5 \\
\hline MM 510 & 15 & 0.67 & $0.54 \mathrm{~b}$ & $8.0 \mathrm{~b}$ & $1.8 \mathrm{ab}$ & 9 & 2.4 \\
\hline SRM & 15 & 0.74 & $0.59 \mathrm{a}$ & $8.8 \mathrm{a}$ & $2.0 \mathrm{a}$ & 9 & 2.7 \\
\hline PAV & 21 & 0.47 & $0.36 \mathrm{~d}$ & $7.5 \mathrm{~b}$ & $2.1 \mathrm{a}$ & 15 & 2.8 \\
\hline PBV & 19 & 0.45 & $0.34 \mathrm{~d}$ & $6.5 \mathrm{c}$ & $1.7 \mathrm{~b}$ & 14 & 2.5 \\
\hline
\end{tabular}

${ }^{2} \mathrm{APM}=\mathrm{Al}$-par planting mix; MM $510=$ Metro Mix 510; SRM = Suremix Rockwool Mix PAV = peat A/vermiculite; PBV = peat B/vermiculite.

yFertilizer was applied between 12 Sept. and 29 Oct. 1989.

${ }^{x}$ Mean separation by Duncan's multiple range test, $P \leq 0.05$.

remains in the root medium. For example, PAV was fertilized 15 times for a total of 2.8 $\mathrm{g} \mathrm{N}$, and SRM was fertilized nine times for a total of $2.7 \mathrm{~g} \mathrm{~N}$ fertilizer. Thus, the reduction in the number of fertilizations was compensated for by an increase in the amount of fertilizer that was applied at any one irrigation.

Another possible misconception about root media that hold large amounts of water is that they will automatically reduce the amount of water and fertilizer runoff. While it is true that root media with a high water-holding capacity can be irrigated less frequently than root media with a lower water-holding capacity, more water needs to be applied at each irrigation. If the leaching fraction is maintained at a constant for both types of media, more water is leached at any one irrigation for media with high water-holding capacity. Over the entire production time, the total amount of irrigation water leached from both types of root media would be similar for similar-sized plants.

If the volume of water leached per pot from media with low and high water-holding capacity is fixed, then over an entire production time, less water will be leached from the media with the higher water-holding capacity because they are irrigated less frequently. The leaching fraction will also be less for the root media with high water-holding capacity. Yelanich and Biernbaum (1993) concluded that leaching fraction and fertilizer concentration as well as the amount of fertilizer removed from the root media determined root-zone nutrient concentrations. If the leaching fraction of a root medium with a high waterholding capacity is reduced, it is likely that the concentration of the applied fertilizer solution will also need to be reduced to prevent fertilizer accumulation.

Table 2. Plant characteristics of poinsettias grown in five root media after week 14 harvest.

\begin{tabular}{lccccc}
\hline \hline Root media $^{\mathrm{z}}$ & $\begin{array}{c}\text { Shoot ht } \\
(\mathrm{cm})\end{array}$ & $\begin{array}{c}\text { Fresh wt } \\
(\mathrm{g})\end{array}$ & $\begin{array}{c}\text { Dry wt } \\
(\mathrm{g})\end{array}$ & $\begin{array}{c}\text { Leaf area } \\
\left(\mathrm{cm}^{2}\right)\end{array}$ & $\begin{array}{c}\text { Bract area } \\
\left(\mathrm{cm}^{2}\right)\end{array}$ \\
\hline APM & $22.3 \mathrm{cb}^{\mathrm{y}}$ & $67.8 \mathrm{c}$ & $10.9 \mathrm{~cd}$ & $915 \mathrm{~b}$ & $1836 \mathrm{~cd}$ \\
MM 510 & $20.0 \mathrm{c}$ & $77.4 \mathrm{c}$ & $10.1 \mathrm{~d}$ & $882 \mathrm{~b}$ & $2457 \mathrm{~b}$ \\
SRM & $29.3 \mathrm{a}$ & $116.7 \mathrm{a}$ & $16.3 \mathrm{a}$ & $1526 \mathrm{a}$ & $3250 \mathrm{a}$ \\
PAV & $24.8 \mathrm{~b}$ & $91.4 \mathrm{~b}$ & $13.7 \mathrm{~b}$ & $1423 \mathrm{a}$ & $2299 \mathrm{cb}$ \\
PBV & $24.0 \mathrm{cb}$ & $78.0 \mathrm{c}$ & $11.8 \mathrm{c}$ & $1358 \mathrm{a}$ & $1636 \mathrm{~d}$ \\
\hline
\end{tabular}

${ }^{\mathrm{z}} \mathrm{APM}=\mathrm{Al}$-par planting mix; MM 510 = Metro Mix 510; SRM = Suremix Rockwool Mix; PAV = peat A/ vermiculite; $\mathrm{PBV}=$ peat $\mathrm{B} /$ vermiculite.

${ }^{y}$ Mean separation by Duncan's multiple range test, $P \leq 0.05$.

\section{Literature Cited}

Argo, W.R. and J.A. Biernbaum. 1993. Factors affecting garden performance of flowering plants in hanging baskets. Bedding Plant Foundations Res. Rpt. F-061 and F-061A.

Argo, W.R. and J.A. Biernbaum. 1994. Irrigation requirements, root-medium $\mathrm{pH}$, and nutrient concentrations of Easter lilies grown in five peat-based media with and without an evaporation barrier. J. Amer. Soc. Hort. Sci. 119:11511156.

Biernbaum, J.A. 1992. Root-zone management of greenhouse container-grown crops to control water and fertilizer use. HortTechnology 2:127132.

Biernbaum, J.A., R. Heins, and W. Carlson. 1989. Limiting runoff with slow release fertilizers, quality media, wetting agents and gels. GrowerTalks 53(5):48-52.

Bilderback, T.E., W.C. Fonteno, and D.R. Johnson. 1982. Physical properties of media composed of peanut hulls, pine bark, and peatmoss and their effects on azalea growth. J. Amer. Soc. Hort. Sci. 107:522-525.

Brown, O.D.R. and E.R. Emino. 1981. Response of container-grown plants to six consumer growing media. HortScience 16:78-80.

Bunt, A.C. 1988. Media and mixes for containergrown plants. 2nd ed. Unwin Hyman, London.

Fonteno, W.C., D.K. Cassel, and R.A. Larson. 1981.
Physical properties of three container media and their effect on poinsettia growth. J. Amer. Soc. Hort. Sci. 106:736-741.

Fonteno, W.C. and P.V. Nelson. 1990. Physical properties of and plant response to rockwoolamended media. J. Amer. Soc. Hort. Sci. 115:375-381.

Ku, C.S.M. and D.R. Hershey. 1991. Leachate electrical conductivity and growth of potted poinsettia with leaching fractions of 0 to 0.4 . J. Amer. Soc. Hort. Sci. 116:802-806.

Nelson, P.V. 1991. Greenhouse operation and management. 4th ed. Reston Publishing Co., Reston, Va.

Puustjarvi, V. and R.A. Robertson. 1975. Physical and chemical properties of peat, p. 24-36. In: D.W. Robinson and J.G.D. Lamb (eds.). Peat in horticulture. Academic, London.

SAS Institute. 1982. SAS user's guide and SAS statistical procedures. SAS Inst., Cary, N.C.

Warncke, D.D. 1986. Analyzing greenhouse growth media by the saturation extraction method. HortScience 21:223-225.

Warncke, D.D. and D.M. Krauskopf. 1983. Greenhouse growth media: Testing and nutrition guidelines. Michigan State Univ. Ext. Bul. E-1736.

Yelanich, M.V. and J.A. Biernbaum. 1993. Rootmedium nutrient concentrations and growth of poinsettia at three fertilizer concentrations and four leaching fractions. J. Amer. Soc. Hort. Sci. 118:771-776. 